\title{
Elite Capture in Local Fishery Management - Post-socialist Experiences from Albania
}

\author{
Oscar Schmidt ${ }^{1}$ and Insa Theesfeld ${ }^{2}$
}

Local self-governance based on institutions for collective action can help overcome social dilemmas in the management of complex Common Pool Resources, such as fish. A common path towards local self-governance is decentralization, and within this context, a transfer of property rights from central government to local resource users. Yet, despite the well-documented successes of many decentralization policies in support of local common property regimes, the phenomenon of elite capture remains a risk. This paper investigates elite capture in Albania's Lake Ohrid fishing region. Our empirical findings draw onto an in-depth case study on local consequences of 2002's decentralization efforts by the Albanian fishery administration. We show how 'blueprint' approaches, top-down implementation, and weak institutions led to further empowerment of privileged locals. Our findings further indicate how those privileged locals realize significant personal gains at the expense of distributional inequity within the community. Specifically original insights are derived from our analysis of implications from the post-socialist context, which we show to facilitate capture because of a common susceptibility for destructive leadership and a lack of confidence in collective action. We believe that to understand those contextual peculiarities - and to act upon this understandingrepresents a pivotal prerequisite to the functional and equitable governance of common property regimes in any transitional society.

Key words: Local governance; Elite capture; Decentralization; Fishery; Albania

\section{INTRODUCTION}

Fishing, a major source of subsistence for many poor, rural households in Albania, has been drastically affected by political and economic changes that began in 1990 . As in all post-socialist countries in Central and Eastern Europe, Albania, experienced a phase of political insecurity and an institutional vacuum after 1990 (Theesfeld 2008; Schleyer 2003). As a result of this political instability, access to resources became unrestricted and it grew impossible to overcome the destructive patterns that typically emerge when rivals compete for common-pool resources (Ostrom 1990). ${ }^{3}$

At Lake Ohrid, the topic of this study, the effective local rule that evolved during this period seems to be open access, that is, no property regime. The previous reaction

\footnotetext{
${ }^{1}$ Humboldt-Universität zu Berlin, Department of Agricultural Economics, Division of Resource Economics. Philippstrasse 13, Building 12. D-10115 Berlin, Germany. Phone: +49 (0)30 20936225. E-mail: oscar.schmidt@staff.hu-berlin.de

${ }^{2}$ Leibniz Institute for Agricultural Development in Central and Eastern Europe (IAMO), Department External Environment for Agriculture and Policy Analysis (Agricultural policy). Theodor-Lieser-Strasse 2. D-06120, Halle (Saale), Germany. Phone: +49 (0)345 2928 138. E-mail: theesfeld@iamo.de

${ }^{3}$ Common-pool resources, including fish, can be managed by a variety of property regimes ranging from government to common property, and from privately owned to open access. In contrast, overfishing will occur whenever the enforcement of property rights remains insufficient and whenever clearly defined rules are absent (Schlager 1994).
} 
to the country's devastated state of its fish resources had been a call to strengthen state management regimes. ${ }^{4}$ Recently, however, Albania has followed the current international trend of decentralization, which has seen at least 60 countries claim to decentralize some aspects of their natural resource management (Agrawal 2002). The Albanian government, together with the World Bank, implemented a commonproperty resource regime in fishery management to reform and decentralize ${ }^{5}$ the existing fishery sector and increase the involvement of local actors.

Most theorists and policy makers justify decentralization on the grounds that the increased efficiency, equity, and inclusion that should arise from the devolution of power and responsibilities result in more sustainable management (Larson \& Ribot 2004). However, while decentralization promises benefits to those who are empowered, it likewise threatens central authorities and elites who fear a potential loss of influence, income, or patronage resources. In this situation, the strength and manifestations - or more specifically, local power relations - of elite actors are exceedingly important in shaping the actual degree of decentralization and its outcomes (Larson \& Ribot 2004; Larson 2003). In many cases, elites interfere until the initial purpose of decentralization is twisted around, leaving those who deserve empowerment with even less, and capturing additional benefits for those in power.

The aim of this study is to confirm and explain the occurrence of elite capture within the scope of current decentralization efforts in Albania's Lake Ohrid fishery. We analyze the specific causes and effects of elite capture on the ground by scrutinizing the aspect of equity. We contribute to the current literature by identifying and emphasizing determinants, including post-socialist particularities, which increase the risk for elite capture to occur. The paper proceeds as follows. In the next section we briefly explain how local governance can successfully manage natural resources. Section 2 introduces the phenomenon of elite capture and emphasizes its potential effects on decentralization policies in natural resource management. Section 3 describes the pre- and post-socialist management regimes in the Lake Ohrid fishing sector. Section 4 provides empirical evidence for the elite capture phenomenon that has taken place at Lake Ohrid. Section 5 concludes with some recommendations for reducing the likelihood of elite capture in a post-socialist society.

\section{LOCAL GOVERNANCE TO SOLVE COMMON-POOL RESOURCE DILEMMAS IN NATURAL RESOURCE MANAGEMENT}

Fishing represents a classical common-pool resource dilemma, which is better described as an open access property regime (Munro 2008). The subtractability of the resource unit, i.e. the fact that the fish one person catches from the common pool are not available to others, adds to the problem of gear conflict and gear congestion. In addition the damage that can be done to the breeding stocks or nursery grounds by short-sighted fishing practices can have serious consequences for everyone who seeks to exploit the same stocks in the future. Although rules concerning property rights could help to control this exploitation, it often remains difficult to effectively implement such rules because it is in the individual fisher's best interest to avoid being constrained (Munro 2008; Acheson \& Knight 2000). Previous conventional

\footnotetext{
${ }^{4}$ This plea was largely in line with Albania's political history as a post-socialist country, where all natural resource management was state managed and top-down implemented and enforced.

${ }^{5}$ Decentralization involves the transfer of power from the central government to actors at the lower local level in a political-administrative and territorial hierarchy (Agrawal \& Ribot 1999).
} 
approaches to overcome this social dilemma included creating a system of solely private property rights or continuing to rely on centralized government control.

However, since at least the early 1980s, scholars have compiled mounting evidence of a variety of problems that may arise from centralized and top-down controlled natural resource management (Dasgupta 1982; Runge 1986; Ostrom 1990; Berkes \& Pomeroy 1997; Agrawal \& Gibson 1999; Andersson \& Ostrom 2008). Criticism of such radical forms of state management has largely centred on the observation that bureaucrats lack contextual information and that this constraint often leads to simplification, 'blueprint' approaches, and insufficient management decisions (Korten 1980; Hannesson 1985; Young 1998; Pistor 2002; Ostrom 2007). Purely statemanaged regimes are therefore often comparatively costly in terms of monitoring and enforcement and often fail to secure access and withdrawal rights.

Quite similar problems may arise in private property regimes, which also disqualifies the second of the two frequently proposed approaches. In private property regimes those claiming an exclusive right automatically face considerable costs to actually secure this exclusivity. There are expenditures for limiting resource access and sanctioning illegitimate beneficiaries. These expenditures, which correlate with the physical attributes of the resource as well as the functioning of the associated institutional structure, often become prohibitive once they must be carried by a single or only a few actors (Ostrom et al. 1994). It follows that if exclusion cannot be guaranteed, then private property will also not guarantee sustainable and equitable use. Despite contrary assignments for its use, the resource will be used within a factual open-access property regime and the "tragedy of open access" will remain a likely threat.

In the light of these observations, many researchers have proposed local governance based on common property as a more suitable alternative to overcome the social dilemma (Ostrom 1990; Bromley \& Feeny 1992; Pomeroy 1995). Promoters of local governance commonly point to the positive effects of including resource users and their knowledge of the resource in the governance process (Ostrom 2005). It has been argued that local knowledge derived from life-long experiences and experience with the natural system in question provides the intellectual inputs that are often lacking from centralized approaches. Andersson and Ostrom (2008) accordingly reason that local actors can use their knowledge to craft better adapted rules than any other general scheme would be able to.

The advantages of locally crafted rules are, however, not only related to their functional suitability. Over and above, it has been emphasized that those who make the rules receive positive effects that stem from the high degree of the rules' legitimacy (Jentoft 1989). Rules that are perceived as legitimate will be strengthened by intrinsic motivation (Frey \& Oberholzer-Gee 1994). The costs of enforcement will be lower than for rules which have been imposed by external forces, such as is the case in coercive, top-down regimes. Today, these advantages that may accompany local governance are also reflected outside the associated research community.

Accordingly, it has been found that many development agencies, donors, NGOs, and policy makers have chosen to incorporate local resource users and their empowerment into their agendas (Blair 2000). 


\section{ELITE CAPTURE IN NATURAL RESOURCE MANAGEMENT}

Despite ample empirical proof for the successes of local governance, there are also various examples in which it has failed to meet its goals. Reviews of decentralization policies and community-based development projects, for instance, indicate that they have not been very effective at targeting the poor (Bardhan, 2002; Mansuri \& Rao 2004). One of the central causes for this failure which has been shown to be particularly relevant in rural and agricultural societies is the problem of elite capture (Mansuri \& Rao 2004; Bardhan 2002; Johnson 2001; Agarwal 2001; Platteau \& Gaspart 2003a; Platteau \& Gaspart 2003b; Platteau 2004; Dasgupta \& Beard 2007; Andersson \& Ostrom 2008). Elite capture is the frequent tendency of local elites -that is, local individuals or groups with disproportionate access to social, political, and economic power -- to dominate or capture participatory projects (Mansuri \& Rao 2004; Banerjee et al. 2001; Dasgupta \& Beard 2007). A typical outcome of elite capture is the misappropriation or illegitimate re-distribution of resources (Platteau 2004; Andersson \& van Laerhoven 2007; D'Exelle \& Riedl 2008). Andersson \& Ostrom (2008: 75) who term these phenomena "local tyrannies", stress that misappropriation is often based on a change of rules by the powerful and that local resource governance systems are therefore often organized anything but democratically (Andersson \& Ostrom 2008).

As stated above, some degree of elite domination may be inevitable in a community participation project, particularly in rural areas where the elites are often leaders who embody moral and political authority. However, due to the elites' ability to communicate with outsiders, read project documents, keep accounts and records, and write proposals they are often the ones crafting the project rules and policy measures that are biased towards them. Therefore, the process of rule making, which was earlier characterized as an outstanding opportunity to create functionally appropriate and legitimate management schemes, has the potential to be abused to meet the preferences of the powerful few (Theesfeld 2008; Andersson \& Ostrom 2008). This in turn may discourage other community actors from participating. In that respect, decentralization can even aggravate the elite capture problem.

The elite capture problem is connected to the question whether actors' heterogeneity will facilitate or constrain collective action and true participation? Manifold studies represent a continuum of opinions on the causality between heterogeneity and collective action (Mansuri \& Rao 2004; Theesfeld 2009), including Olson (1973), who argues that certain types of inequality will favour the provision of a public good. Likewise, Wade (1987) argues that it may be necessary to organize around existing structures of authority, with a major role played by village elites. In fact, many cases indicate the positive effects and the importance of skilled and influential leaders in the course of self-organizing processes in ecosystem management (Folke et al. 2005; Olsson et al. 2007; Meinzen-Dick et al. 2002; Johnson 2001; Calvert 1992; and Olsson et al. 2007). Hurrelmann et al. (2006) stress the role of appropriate mediating agencies involved, finding that particularly in post-socialist countries with low social capital, well-educated and well-connected local leaders can initiate and maintain local cooperation.

Other authors qualify this viewpoint by arguing that the polarizing effect of heterogeneity depends on how collective action is organized (Heckathorn 1993). Dayton-Johnson and Bardhan (2002), for instance, show that the relationship between inequality and levels of collective action in conservation can be U-shaped in 
the fishery sector. Fishers who have outside earnings opportunities may believe that increased inequality has a negative effect on conservation. However, as inequality increases, the levels of conservation can improve and perfect conservation of the resource is possible under perfect inequality.

Finally, authors such as La Ferrara (2002) find that a greater level of village inequality in rural Tanzania reduces the probability of participation in any group. Bardhan (2000), examining the factors affecting irrigation maintenance in South India, finds that inequality has a negative effect. Likewise, Blomquist et al. (2005) emphasize that extreme asymmetries in resource endowments among actors can imperil the success of decentralization efforts. In line with the discussion on the degree to which heterogeneity favours or hinders collective action, we must further distinguish carefully between elite domination and elite capture. Rao \& Ibanez's (2003) case study shows the potentially more benevolent form of elite domination, with more than 90 percent of beneficiaries ultimately expressing satisfaction with the project.

Conditions that increase the likelihood for elite capture are manifold and can be related to exogenous grievances as well endogenous structural and cultural imperfections within the community itself (Berkes \& Pomeroy 1997; Platteau \& Abraham 2002). The risk for elite capture is surpassingly high whenever local governance is sought and introduced by external actors, as it is, for instance, in international development programs or rural development policies (Platteau 2004).

External actors who aim to introduce local governance typically make some form of investment in the community, perhaps in the form of political empowerment in terms of enhanced decision making rights or the devolution of management responsibility. Other forms may be financial and material contributions or the assignment of exclusive property rights in a specific natural resource system. Again, other investments may take the form of training for capacity building and the assistance of constitutional choices. All of these investments are usually channelled through a small number of community representatives and the local elites will almost naturally be among this group (Platteau 2004).

Leadership may result in abuse and capture when those in power cannot be held accountable for their decisions and actions. Once an investment has been disbursed, external actors are often prone to losing track of what is actually happening within the community (Platteau \& Abraham 2002). This is predominantly the case when those in charge of channelling the investment are the only actors with whom the external donor agency has established close and repetitive contact (ibid.). The elites can then abuse their privileged position to filter inquiries regarding the whereabouts and use of the donor's contributions and, thus, create an opportunity to capture a disproportionate share for their own personal benefits. In other cases, the external donor agency may simply lack the resources or even the tenacity to follow up on the long term effects of its investments. In cases such as these, there is undoubtedly even more freedom to dominate community-level planning and corrupt the use of assets.

Yet another problem related to channelling external investments through a powerful few is that these actors can dictate the expectations of the intended beneficiaries, that is, the ordinary community members. In this case, the community members do not know that they are being cheated and thus can offer no opposition. A lack of opposition from within the community is not always a consequence of asymmetric 
information. Platteau (2004) argues that elite capture is often tolerated or even supported once the powerful are recognized as the only actors holding the capacity, education, and influence to acquire or deal with external sources of funding. In cases such as these, we often find the relationship between the powerful and the weak to be clientelistic and that abuses are tolerated as long as the patron meets the client's demands (Platteau 2004).

Although it is a group' responsibility to solve its coordination problems, changing leaders is difficult and costly, thus, leaders always have some leeway for side payments and other private benefits (Calvert 1992). Luthans et al. (1998) particularly ask why post-communist countries as Albania are susceptible to the power of destructive leaders, even after the demise of communism. They conclude that the historical and cultural foundations are decisive when combined with current economic, social, and political crisis. One characteristic of this dilemma is the fact that destructive leaders in these countries traditionally use the unlimited power of the former Communist party to maximize their own political survival.

\section{NATURAL RESOURCE MANAGEMENT REGIMES IN PRE- AND POST SOCIALIST LAKE OHRID FISHERY}

The Lake Ohrid fishing industry provides empirical evidence to confirm these dynamics and their associated explanations. The study is based on an analysis of primary and secondary data obtained during a two-month field visit in 2008 . The data presented was collected in three fishing communities: the littoral villages of Hudenisht and Lin and the town of Pogradec. We visited these sites repeatedly to meet with the interviewees and make on-site observations.

The two villages and the town of Pogradec were selected based on an explorative prior inquiry which indicated a range of advantages, including (1) the comparatively large size of their fishing communities and the diversified composition of their members, (2) their prominent role within the local governance framework, and (3) their accessibility. In the three communities a total sample of 25 semi-structured open-ended interviews were conducted. Besides fishermen (18 interviews), who were the key actors in our analysis, representatives of associated economic sectors such as the local fish trade and consumption were interviewed (three interviews). Further interviews were conducted with fishing experts including staff members from the local and national fishery administration, local NGOs, and the World Bank (four interviews). Additional primary data were collected through informal conversation ${ }^{6}$ and observational techniques (both direct and participatory). A variety of contextrelated documents and archival records were included as secondary data. Data were verified by triangulation.

\section{(a) Fishery management before the introduction of local governance}

The Lake Ohrid fishing industry has seen various periods of fundamental institutional change ${ }^{7}$. During Communist reign, from 1947 to 1991, fishing was the exclusive domain of the centralized state. Resource use by private entities was prohibited and

\footnotetext{
${ }^{6}$ The technique of informal conversation resembles unstructured, open interviews. It differs however, from the latter, because it evolves exclusively by chance and without a strict assignment of the interviewee and interviewer roles (Yin 1994).

${ }^{7}$ Institutional change can occur intentionally or spontaneously (Hayek 1964, North 1990).

Furthermore, institutional change can have both intended and unintended outcomes (Kingston \& Caballero 2009).
} 
decisions on withdrawal rates and maintenance were exclusively planned and organized by the central authorities in Tirana. Those decisions were then passed to local state enterprises for execution. At Lake Ohrid, the Pogradec Fishery Enterprise, a cooperative which comprised 40 fishermen, was assigned with these obligations. Harvest rates during this period were sufficiently low and stable to sustain the existing population. Any profits from selling the fish flowed back to the state budget. The cooperatives' employees received fixed monthly salaries that were independent from the enterprise's performance. Illegal fishing - at least by external actors - was nonexistent due to the fact that the lake was considered a top-security military zone wherein trespassers would be immediately detected.

This organizational structure changed radically in the course of Albania's political transition. In 1992, state-imposed restrictions that had provided strict order and predictability quickly lost their authority and became ineffective. The state cooperative at Lake Ohrid was dissolved, and resource use was opened to anybody who was willing to take the opportunity.

Three years later, in 1995, Albanian authorities adopted the national "Law on Fishing and Aquaculture," introducing a licensing system that allowed private entities to acquire formally recognized property rights to the harvest and use of the country's fish resources. Associated administrative responsibilities, such as the issuing of licences and surveillance and execution of the fishery regulations, were assigned to the newly established Directorate of Fisheries Policies (DoF) and its 14 regional divisions. The execution of fishery management at Lake Ohrid was consequently entrusted to the DoF's divisional office in the district of Korçë. ${ }^{8}$ With the new management system in place, about 120 fishermen and their companions purchased licenses and were officially entitled to exploit the lake. An unknown number of unlicensed fishermen remained in business due to weak law enforcement.

Changes in the Lake Ohrid fishing sector were not limited to property rights, management rules, or the composition of actors; fishing patterns and harvest rates also were altered significantly. The amount of fishing intensified as incomes increased due to competition. In order to achieve higher revenues, fishermen therefore started to adjust, both, their fishing gear, as well as the number of workdays. This already critical situation was further aggravated during the countrywide uprisings and political instability in 1997 and 1998. Following these incidents about 350 additional boats entered Ohrid without permission, severely increasing, yet again, the number of actors exploiting the lake. Poaching and the disrespect of gear restrictions quickly evolved to become daily routines and fish stocks declined at an even more alarming pace (Latzinger et al. 2006; Watzin 2006).

\section{(b) The initiation and implementation of local governance}

Early in this decade international donors began to push for nationwide measures to combat illegal fishing and increase the sector's economic performance. The World Bank, a leading international donor in Albania, implemented the Pilot Fishery Development Project (PFDP) with a primary goal of introducing local governance for the country's marine and inland fish resources; Lake Ohrid was one of 14 target areas for implementation (World Bank 2000).

\footnotetext{
${ }^{8}$ During the period of our analysis, the divisional office was run by a single inspector whose responsibilities covered the $\sim 109 \mathrm{~km}^{2}$ of lake territory belonging to Albania, as well as all other fishery related issues within the district.
} 
In 2002, the year the PFDP and its measures were to be executed, they received formal recognition through an amendment of the national fishery legislation. Albanian policy makers accordingly followed the World Bank's pledge to formalize local governance as a legally binding process. However, this policy reform was based on coercive measures. According to the PFDP's framework and the associated legislation, local fishermen were formally obliged to participate in the governance process and organize in local Fishery Management Organisations (FMO). In other words, the fishers were forced to join the newly created organizations to retain their fishing rights.

Fourteen local organizations were established at various sites in the country, including Lake Ohrid, during the 5 years of the project. Each FMO was entrusted with management duties and exclusive fishing rights for a defined territory. All 14 organizations were created under the same statute, regardless of whether they were set up to deal with the management of the high seas, the coast, or inland watersheds. The statute spelled out the FMOs' organizational structure, defining membership rules, positions, and responsibilities; decision-making and conflict resolution procedures; and contribution and pay-off distribution. Our interviews with members of the national fishery administration indicate that this statute had been solely designed by a Norwegian consultancy firm. This also indicates that there was little if any participation by stakeholders from the fishery sector and that local knowledge had largely been disregarded.

At Lake Ohrid, the Pogradec Fishery Management Organisation was formally assigned as the sole entity holding fishing rights and management duties. The project personnel chose a small group of fishers to be leaders in an effort to include the local community in the implementation process. It was hoped that those who were selected as leaders would represent and promote the FMO within the community and serve as counterparts to the project staff and administration. They were also appointed to leading positions on the organization's Administrative Council, which gave them exclusive rights to elect the organization's chairman; call meetings; and determine the amount, distribution, and use of financial contributions, by FMO members. Furthermore, the chairman and the Administrative Council were made solely responsible for all communications and any other interactions with external actors such as the administration, market actors, or the PFDP.

In one of our interviews a PFDP representative justified the selection of these actors by stating that those who were chosen were both "skilled and influential" and that they were "the only ones willing and prepared to take such responsibilities." The fact that the new leaders simultaneously belonged to a small number of fishermen who could - and still can - afford to engage in the costly yet productive net fishing business was declared a "coincidence" which the project did "not intend" to produce, but which "did not meet any local opposition anyhow." 910

\footnotetext{
${ }^{9}$ Estimations by the administration indicate that the approximately $30 \mathrm{FMO}$ members who can afford to engage in costly net fishing currently skim up to $80 \%$ of the lake's total production.

${ }^{10}$ This "coincidence" of economic power and leadership - to adopt the second, alternative meaning of the expression - can surely not be taken as proof for an agenda to further empower the already powerful. The fact that there seems to have been no opposition or demands by weaker members may, however, be regarded as an indication of biased selection.
} 
The same interviewee confirmed that the maximum number of ordinary members allowed to join the FMO was determined by the national department of the DoF and initially set at 140 . These 140 included a large share of the 120 fishermen who had already held licences since the mid 1990s. The remaining licences were distributed to newcomers. Around two-thirds of the total number of ordinary FMO members were - and today remain - engaged in the cheap but relatively unproductive hookand-spoon-bait fishery. Not only were these actors appointed to lower positions within the organization; they were also economically less successful than those installed as leaders by the PFDP.

In addition to the licensed fishers, a large number of illegal fishers remained. Although these illegal fishers were considered to be criminals who should face punishment and banishment from the lake, the administration, like those of the past, declined to enforce the new measures. As a consequence, illegal fishing was not eradicated - the local fishery inspector even described the current situation as having "gotten worse" - and the FMO was by no means vested with the exclusive property rights that had been promised by the legislation. As a result, heterogeneity within the community was significantly increased by the PFDP's appointment of the economically powerful to leading positions. The perhaps most striking result was that the economically advantaged were granted an additional and disproportionate share of political power, whereas the economically weak lost ground by being palmed off with ordinary membership positions.

\section{ELITE CAPTURE AT LAKE OHRID}

Seven years after the establishment of the Pogradec Fishery Management Organisation at Lake Ohrid, the arbitrary condition characterized by licensed resource use, poaching, and insufficient law enforcement has been aggravated. Overfishing has remained unchanged, a fact confirmed by stakeholders who frequently complain about the severe decline of productivity. Local governance is absent and fishery legislation non-compliance continues to be widespread. Unlicensed fishermen are truly an unchanged problem and many stakeholders accordingly blame this group for having caused the resource's current state. Our analysis, however, indicates that a considerable share of these problems is in fact caused by the few influential actors who were initially chosen as FMO

representatives. The privileged positions these actors were granted by the PFDP are an important source to further reinforce their already disproportionate degree of economic and political power. This power was found to be used as the basis for a well organized system of elite capture.

Our data indicate that elite capture at Lake Ohrid mainly takes the form of misuse of information by the administration and re-distribution of contributions by the PFDP. More concisely, elite actors abuse their authority to avoid sanctions, illegally support their kin, and construe the legal framework in accordance with their preferences. The system of capture permits some to be beneficiaries while others suffer a considerable loss of utility and an interference with their property rights.

The demarcation between winners and losers does not follow the simple pattern of the wealthy and powerful characterized as winners and the poor and disempowered deemed losers. In contrast, we found that patronage and kinship allowed some actors who belong to the latter group to be counted as beneficiaries as well.

Participatory observation accordingly showed that both ordinary FMO members and illegal fishers are frequently supported by the powerful few. The beneficiaries are 
predominantly the elite's family or clan members, close neighbors, and business partners. Thus, the determination of beneficiaries and losers is by social affiliation rather than FMO membership or legal entitlement. ${ }^{11}$

A continuous misuse of information by elite members can occur. Notes on upcoming inspections or other measures are given to the FMO's Administrative Council prior to their execution. This procedure is supposedly meant to foster local participation and assistance, but is in fact used as an opportunity to cover up wrongdoings. Illegal nets are hauled in and hidden and unlicensed companions are informed to leave on time. As the following example shows, even these measures of avoidance are unnecessary for the elite.

In early 2006 the DoF detected various cases of illegal fishery by FMO members. Allowable mesh sizes and other gear restrictions had been ignored and undersized fish had been caught and sold en masse. Yet, while some of the ordinary FMO members received fines and lost their fishing rights, no such sanctions were placed on the FMO leaders. Table 1, below, illustrates a striking incongruity between formal and informal rules on various transactions from fishery practice. The informal rules that in reality organize the transactions and relationships in the fishery sector are shown to offer a variety of comparative advantages to the local elite and their kin. Instead of supporting the formal rules, these fishers therefore reinforce the informal set of rules and thereby their dominant position and profits.

\footnotetext{
${ }^{11}$ Actors who in contrast complained to remain without any such support underscored this finding by explaining that their exclusion resulted from missing social ties.
} 
Incongruent formal and informal rules indicating power abuse and elite capture

\begin{tabular}{|c|c|c|}
\hline & Formal rules $^{a b}$ & $\begin{array}{l}\text { Informal rules enforced through power } \\
\text { abuse }\end{array}$ \\
\hline \multirow[t]{2}{*}{$\begin{array}{l}\text { (1) - Access to } \\
\text { fishing spots and } \\
\text { withdrawal rights }\end{array}$} & $\begin{array}{l}\text { Each member of the FMO has the right } \\
\text { to fish within all waters of the co- } \\
\text { management area. }\end{array}$ & $\begin{array}{l}\text { Fishing spots and coastal territories are } \\
\text { distributed internally and in accordance with } \\
\text { the power of each claimant. Those with the } \\
\text { greatest influence also control the most } \\
\text { productive spots. }\end{array}$ \\
\hline & $\begin{array}{l}\text { No person may undertake any fishing } \\
\text { activities within the co-management } \\
\text { area unless he/ or she is a member of } \\
\text { the FMO. }\end{array}$ & $\begin{array}{l}\text { Powerful actors allow accomplices without } \\
\text { FMO membership to fish in the territories } \\
\text { they control. }\end{array}$ \\
\hline $\begin{array}{l}\text { (2) - Property rights } \\
\text { assigned to licenses }\end{array}$ & $\begin{array}{l}\text { A single license holds validity for a } \\
\text { captain, his/her boat and gear, and a } \\
\text { single assistant. }\end{array}$ & $\begin{array}{l}\text { Wealthy fishermen, such as the FMO } \\
\text { chairpersons, illegally employ groups of up } \\
\text { to ten assistants to increase their revenues. }\end{array}$ \\
\hline $\begin{array}{l}\text { (3) - Restrictions on } \\
\text { species and sizes }\end{array}$ & $\begin{array}{l}\text { Catches must not include fish below a } \\
\text { clearly defined minimum body size and } \\
\text { age. }\end{array}$ & $\begin{array}{l}\text { Undersized fish are commonly caught and } \\
\text { openly marketed. }\end{array}$ \\
\hline $\begin{array}{l}\text { (4) - Gear } \\
\text { restrictions }\end{array}$ & $\begin{array}{l}\text { Clearly defined restrictions exist for } \\
\text { mesh sizes in nets, the types and } \\
\text { numbers of hooks per boat, and the } \\
\text { capacities of outboard engines. }\end{array}$ & $\begin{array}{l}\text { Gear restrictions are systematically } \\
\text { disrespected. }\end{array}$ \\
\hline $\begin{array}{l}\text { (5) - Banning } \\
\text { periods }\end{array}$ & $\begin{array}{l}\text { There are clearly defined banning } \\
\text { periods to secure the reproduction of } \\
\text { the threatened stocks. }\end{array}$ & Banning periods are regularly disrespected. \\
\hline \multirow[t]{2}{*}{$\begin{array}{l}\text { (6) - Monitoring and } \\
\text { sanctioning }\end{array}$} & $\begin{array}{l}\text { The local DoF representative must } \\
\text { perform regular monitoring rounds and } \\
\text { sanction cases of non-compliance by } \\
\text { issuing fines and withdrawing fishery } \\
\text { licenses. }\end{array}$ & $\begin{array}{l}\text { Monitoring rounds occur irregularly due to } \\
\text { the limited financial and technical capacities } \\
\text { of the local unit of the DoF. }\end{array}$ \\
\hline & $\begin{array}{l}\text { The FMO is given advance notice and } \\
\text { is obliged to support the local DoF } \\
\text { representative on his/her monitoring } \\
\text { rounds. }\end{array}$ & $\begin{array}{l}\text { FMO leaders use their information } \\
\text { advantage to notify their kin whenever } \\
\text { monitoring rounds are about to happen. } \\
\text { Fishermen who do not belong to this } \\
\text { network do not receive notice and remain at } \\
\text { risk. } \\
\text { Sanctions are not enforced due to } \\
\text { exceptions, infringement, and privileges for } \\
\text { actors who network with the local } \\
\text { administration, }\end{array}$ \\
\hline $\begin{array}{l}\text { (6) - Distribution of } \\
\text { licenses and fees }\end{array}$ & $\begin{array}{l}\text { The FMO is assigned to annually issue } \\
\text { licenses and collect and administer } \\
\text { membership fees. }\end{array}$ & $\begin{array}{l}\text { The DoF retained its ability to determine the } \\
\text { number of annual licences. The FMO only } \\
\text { distributes these licenses among its } \\
\text { members. }\end{array}$ \\
\hline $\begin{array}{l}\text { (7) - Establishment } \\
\text { of a binding co- } \\
\text { management plan }\end{array}$ & $\begin{array}{l}\text { The FMO is involved in the preparation } \\
\text { and implementation of the co- } \\
\text { management plan. }\end{array}$ & $\begin{array}{l}\text { The existing management plan has been } \\
\text { drafted by international consultants without } \\
\text { any participation of local fishermen. }\end{array}$ \\
\hline $\begin{array}{l}\text { (8) - Catch statistics/ } \\
\text { reports to the DoF }\end{array}$ & $\begin{array}{l}\text { The FMO is obligated to collect catch } \\
\text { statistics by all fishers on a daily basis } \\
\text { and to submit them to the DoF. }\end{array}$ & $\begin{array}{l}\text { Fishers do not reveal their productivity and } \\
\text { the existing record remains incomplete. }\end{array}$ \\
\hline
\end{tabular}

a According to the national law "On Fishing and Aquaculture" no. 7908 1995; Amendment no. 8870, 2002; Regulation no.1, 1997 and Regulation no. 2, 2005

b According to the Fishery Management Organisation's statute 
Table 1 indicates that those who are disadvantaged within the present system are not only excluded from the additional benefits that the elites capture by avoiding sanctions. In fact, our example shows that a considerable number of benefits are captured at the expense of the disadvantaged actors' property rights (see Table 1: line 1). Another example is the fact that ordinary FMO members are frequently kept in the dark regarding the whereabouts and use of the organization's budget. Fishers provided statements such as, "What budget? I don't know anything about money?" or "I just pay my fee, what they do with it I don't know," obviously underscoring this finding.

Elite capture at Lake Ohrid leads to a range of consequences that directly affect collective action, and thus, the prospects for local governance. Here, heterogeneity and leadership are not drivers but, due to the context, obstacles to collective action. The purchase of licenses and membership in the Pogradec FMO continue to have negligible influence on the chosen operational rules. Interview statements such as, "In the future FMO members will be the first in line to receive money" indicate that licenses and membership are rather used as investments, which may become valuable with future engagement by international donors or an increased exertion of power by the government. ${ }^{12}$

The FMO remains what Theesfeld (2008) has described as a "pseudo-association" for the Bulgarian irrigation sector, existing only as a state imposed formal creation. Its effects include an even further reduction in the willingness to cooperate. This is partly due to the above-mentioned comparative advantages that arise from lax law enforcement and the freedom to construe fishery related rules. The powerful and their kin have accordingly established a beneficial patronage network wherein rule compliance would be tantamount to a loss of utility. The FMO members who are not affiliated with this network are equally reluctant to cooperate, but for different reasons. For those who have had negative experiences with the FMO leaders, collective action could cause them to be deprived of their actual property rights, remaining unheard, and receive disproportionate benefits from joint actions. Interviewees from this group frequently gave statements such as, "I don't trust the FMO"; "The big guys occupy all the good fishing spots and I am left with nothing"; or "They promised us so many things, but nothing was provided."

We have further shown that certain powerful actors within the local community are clearly responsible for the present situation. However, we can also place blame on the PFDP's initiation and implementation strategy and insufficient follow-up measures by the authorities. The introduction of local governance at Lake Ohrid has been a coercive measure that was never requested for by locals. Therefore, it is not presumptuous to say that the PFDP was itself as much of a top-down measure as the purely state managed regimes whose imperfections local governance is ideally meant to offset. The choice of a "one size fits all"-statute for all 14 organizations is only one out of a number of remarkable examples to support this argument. ${ }^{13} 14$

\footnotetext{
${ }^{12}$ Platteau \& Gaspart (2003b: 3) have argued quite fittingly that many local leaders have "understood that the creation of a local NGO has become one of the best means of procuring funds from the international community."

${ }^{13}$ Ostrom (1994: 43) supports this assessment when she states that "even advocates of community based management fall into the trap of blueprint thinking" [...] whenever they "call for the creation of large numbers of $[\ldots]$ organisations in a short period of time."
} 
We further showed that the PFDP solely established contacts with a small number of already advantaged actors, therefore excluding a large share of weaker members of the community. The fact that these very actors are today abusing their privileged positions is an indication that the PFDP simply "skipped" a genuine opportunity to empower weaker fishermen, in the terminology of Platteau \& Gaspart (2003b: 3) in a similar context. The project planners either overlooked the initial distribution of power and resources within the community or ignored its potential consequences. Actual participation opportunities were missed during the different phases of rule-making. This was the result of the PFDP choosing to use external consultants to create both the FMO's statute as well as the co-management plan. Local knowledge and local needs were largely ignored, an assessment which is obvious when reading through the FMO's present co-management plan.

Further causes of this situation include severe shortcomings in follow-up measures and accountability and a lack of sufficient back-up institutions at higher levels of social organization. The local administration was accordingly found to be remiss in fulfilling its responsibilities due a combination of apathy, pessimism, inconsistent behaviour, insufficient capacities, and even infringement. Statements such as, "This is Albania, there is no state!" or "The DOF's inspector can't do anything about poaching" show that stakeholders in the Lake Ohrid fishery sector are well aware of these problems.

The consequences do not end with increased non-compliance. Instead, we also find trust in public support to be severely deteriorated, thus providing another reason for a reluctance to participate in state-run initiatives such as the PFDP. To date there is no evidence for a stronger engagement by superior administrative organs at the national level. In other words, there is no higher level of power to hold accountable actors who do not fulfil their duties or who actively counteract the law. Therefore, weaker local actors cannot call on higher jurisdictional bodies to enforce the law and protect their property rights. This option is, however, essential for sustainable resource management and is part of a "facilitative political regime" (Ostrom 1990: 137; Blomquist 1992).

\section{CONCLUSION}

Although local governance can help overcome social dilemmas in natural resource management, there may also be severe drawbacks with current decentralization policies, such as capture by disproportionately influential actors. Empirical findings in the Lake Ohrid fishery case confirm that this risk increases whenever local governance is introduced by external don ${ }^{1}$ ors who fall back on blueprint thinking and rash implementation measures. Institutional change at Lake Ohrid has been characterized by externally induced adjustments, a strengthening of local elites, and the simultaneous exclusion of weak stakeholders. Follow-up measures to accompany the post-project phase and suitable socio-political and legislative backup institutions at higher levels of social organization were either absent or insufficient.

Today the local elites use the opportunities which arise from their privileged position and the continuous absence of law enforcement to capture a disproportionate share of resources and further enhance their influence. A range of actors holding social ties

\footnotetext{
${ }^{14}$ Ostrom (2007a) likewise expresses her concern against 'one size fits all' approaches within the scope of managing very diversified and complex social-ecological systems.
} 
to the elite can be shown to profit from the resulting manifestation of illegal fishing. In contrast, non-affiliated members of the fishing community suffer a considerable loss in utility and an interference with their formally assigned property rights. Local selfgovernance, as envisioned by the PFDP initiators, does not exist. The annual purchase of fishing licenses and membership in the FMO are used solely as investments, which may become valuable in the case of future expenditures by international donors. The organisation exists solely on paper and thus represents a "pseudo-association."

Our empirical case shows that elite capture can evolve to become a severe problem with negative consequences within at least two dimensions of natural resource use: It simultaneously drives social inequality among local resource users and worsens environmental destruction. Sufficient strategies are needed to avoid this phenomenon. In line with Mansuri \& Rao (2004), we therefore suggest introducing local governance in a context-specific manner with a long time horizon and careful, well-designed monitoring and evaluation systems. This contextual sensitivity is particularly important in post-socialist societies such as Albania because there is a need to account for lost trust and expectations in collective-action-based governance resulting from communist experiences and the ensuing transition.

Furthermore, it is important to be aware that due to chaotic rules and a consequential need for security, societies in transition are exceedingly susceptible to destructive leadership (Luthans et al. 1998). It follows that the goal must be genuine empowerment that allows for factual and repetitive inclusion of all stakeholders within a community. This pledge implies more careful selection of leaders in natural resource management in general, and in local fishing co-operatives in particular. Selecting leaders who are well respected within the village community and have a good reputation may lead to norms of reciprocity that foster cooperation.

The chances of finding such leaders are better if information asymmetry is reduced. In addition, sufficient monitoring and sanctioning rules are required to hold these leaders accountable. Finally, Larson \& Ribot (2004) point to the importance of finding a more sensible and equitable mode of devolution by proposing a public dialogue on topics such as public versus private powers and central versus local control. This is, in fact, exceedingly relevant in post-socialist societies that often lack a tradition of public discourse, particularly regarding methods of splitting property rights.

\section{REFERENCES}

Acheson, James M., and Jack Knight. "Distribution Fights, Coordination Games, and Lobster Management." Comparative Studies in Society and History 42, no. 01 (2000): 209-238.

Agarwal, Bina "Participatory exclusions, community forestry, and gender: An analysis for South Asia and a conceptual framework." World Development 29, no. 10 (2001): 1623-1648.

Agrawal, Arun "The regulatory community: Decentralization and the Environment in the Van Panchayats of Kumaon, India." Mountain Research and Development 21, no. 3 (2002): 208-211. 
Agrawal, Arun, and Clark C. Gibson. "Enchantment and Disenchantment: The Role of Community in Natural Resource Conservation." World Development 27, no. 4 (1999): 629-649.

Agrawal, Arun, and Jesse Ribot. "Accountability in decentralization: A framework with South Asian and West African cases." The Journal of Developing Areas 33, no. 4 (1999): 473-502.

Andersson, Krister P., and Frank van Laerhoven. "From Local Strongman to Facilitator. Institutional Incentives for Participatory Municipal Governance in Latin America." Comparative political studies 40, no. 9 (2007): 1085-1111.

Andersson, Krister P., and Elinor Ostrom. "Analyzing decentralized resource regimes from a polycentric perspective." Policy Sciences 41, no. 1 (2008): 71-93.

Bardhan, Pranab "Decentralization of governance and development." The Journal of Economic Perspectives 16, no. 4 (2002): 185-205.

Bardhan, Pranab "Irrigation and cooperation: An empirical analysis of 48 irrigation communities in South India." Economic Development and Cultural Change 48, no. 4 (2000): 847-865.

Banerjee, Abhijit, Dilip Mookherjee, Kaiwan Munshi, and Debraj Ray. "Inequality, control rights, and rent seeking: sugar cooperatives in Maharashtra." Journal of Political Economy 109, no. 1 (2001): 138-190.

Berkes, Fikret, and Robert S. Pomeroy. "Two to tango: The role of government in fisheries co-management." Marine Policy 21, no. 5 (1997): 465-480.

Blair, Harry "Participation and accountability at the periphery: democratic local governance in six countries." World Development 28, no. 1 (2000): 21-39.

Blomquist, William, Ariel Dinar, and Karin Kemper "Comparison of Institutional Arrangements for River Basin Management in Eight Basins." World Bank Policy Research Working Paper no. 3636. (2005).

Blomquist, William Dividing the waters: Governing groundwater in southern California. San Francisco, CA, Lanham, Md.: ICS Press, (1992); Distributed to the trade by National Book Network.

Bromley, Daniel W. and David Feeney (eds.) Making the Commons Work. Theory, Practice, and Policy. ICS Press, San Francisco, California. (1992)

Calvert, Randall "Leadership and Its Basis in Problem of Social Coordination." International Political Science Review 13, no. 1, (1992): 7-24.

Dasgupta, Aniruddha and Victoria A. Beard "Community Driven Development, Collective Action and Elite Capture in Indonesia." Development and Change 38, no. 2, (2007): 229-249.

Dasgupta, Partha (1982) The Control of Resources. Harvard University Press, Cambridge.

Dayton-Johnson, Jeff and Pranab Bardhan "Inequality and Conservation on the Local Commons: A Theoretical Exercise." Economic Journal 112, no. 481, (2002): 577-602. 
D'Exelle, Ben and Arno Riedl "Elite Capture, Political Voice and Exclusion from Aid: An Experimental Study." Research Memoranda no. 24, METEOR, Maastricht Research School of Economics of Technology and Organization, Maastricht. (2008). Folke, Carl, Thomas Hahn, Per Olsson, and Jon Norberg "Adaptive Governance of Social-Ecological Systems." Annual Review of Environment and Resources 30, (2005): 441-473.

Frey, Bruno \& Felix Oberholzer-Gee "The Cost of Price Incentives: An Empirical Analysis of Motivation Crowding-Out." The American Economic Review 87, no. 4, (1994): 746-755.

Hannesson, Rögnvaldur "Inefficiency Through Government Regulations: The Case of Norway's Fishery Policy." Marine Resource Economics 2, no. 2, (1985): 115-141.

v. Hayek, Friedrich A. „Arten des Rationalismus." In Gesammelte Werke von F.A. von Hayek Freiburger Studien vol 5, 1969, ed. v. Hayek, F.A., J.C.B. Mohr (Paul Siebeck), Tübingen. (1964): 75-89

Heckathorn, David "Collective Action and Group Heterogeneity: Voluntary Provision versus Selective Incentives." American Sociological Review 58, no. 3, (1993): 329350.

Hurrelmann, Annette, Catherine Murray, and Volker Beckmann "Social Capital and Leadership: Rural Cooperation in Central and Eastern Europe." Society and Economy 28, no. 3, (2006): 219-243.

Jentoft, Svein "Fisheries Co-management. Delegating Government Responsibility to Fishermen's Organisations." Marine Policy 13, no. 2, (1989): 137-154.

Johnson, Craig "Community Formation and Fisheries Conservation in Southern Thailand." Development and Change 32, no. 5, (2001): 951-974.

Kingston, Christopher and Gonzalo Caballero. "Comparing theories of institutional change." Journal of Institutional Economics 5, no. 2, (2009): 151-180.

Korten, David C. "Community Organization and Rural Development: A Learning Process Approach." Public Administration Review 40, no. 5, (1980) 480-511.

La Ferrara, Eliana "Inequality and Group Participation: Theory and Evidence from Rural Tanzania." Journal of Public Economics 85, no. 2, (2002): 325-273.

Larson, Anne "Decentralization and Forest Management in Latin America: Toward a Working Model." Public Administration and Development 23, no. 2, (2003): 211-226.

Larson, Anne and Jesse Ribot "Democratic Decentralisation through a Natural Resource Lens: An Introduction." European Journal of Development Research 16, no. 1 , (2004): 1-25.

Latzinger, A., Z. Spirkovski, S. Patceva, and A. Wuest "Sensitivity of Ancient Lake Ohrid to Local Anthropogenic Impacts and Global Warming." Journal of Great Lakes Research 32, no. 1, (2006): 158-179.

Luthans, F., S.J. Peterson, and E. Ibrayeva "The potential for the "dark side" of leadership in post-communist countries." Journal of World Business 33, no. 2, (1998): 185-201. 
Mansuri, Ghazala and Vijayendra Rao "Community-Based and -Driven Development: A Critical Review." The World Bank Research Observer 19, no. 1, (2004): 1-39.

Meinzen-Dick, Ruth, K.V. Raju, and Ashok Gulati "What Affects Organization and Collective Action for Managing Resources? Evidence from Canal Irrigation Systems in India." World Development 30, no. 4, (2002): 649-666.

Munro, Gordon R. "Game theory and the development of resource management policy: the case of international fisheries." Environment and Development Economics 14, (Special Issue 1) (2008): 7-27.

National Fishery Law of Albania no. 7908 "On Fishing and Aquaculture" (1995). In Compendium of Environmental Legislation of Albania. Published by the Republic of Albania, 2004.

National Fishery Law of Albania no. 8870. Amendment to the Law No. 7908 "On Fishing and Aquaculture." Year of enactment (2002). In Compendium of Environmental Legislation of Albania. Published by the Republic of Albania, 2004.

National Regulation no. 1, Regulations for implementation of Law No. 7908 "For fishing and aquaculture." Year of enactment 1997. In Compendium of Environmental Legislation of Albania. Published by the Republic of Albania, 2004.

National Regulation no. 2 "For application of the legislation on fishery and aquaculture." Year of enactment 2005. Online at: http:// www. Dfishery .gov .al /EN /html / Publications.html.

North, Douglas Institutions, institutional change and economic performance. Cambridge University Press, Cambridge. (1990).

Olsson, Per, Carl Folke, and Fikret Berkes "Adaptive Co-management for Building Resilience in Social-Ecological Systems." Environmental Management 34, no. 1, (2007): 75-90.

Olson, Mancur The Logic of Collective Action: Public Goods and the Theory of Groups. Harvard University Press, Cambridge. (1973).

Ostrom, Elinor Governing the Commons. The Evolution of Institutions for Collective Action. Cambridge University Press, Cambridge, New York. (1990).

Ostrom, Elinor "Institutional Analysis, Design Principles and Threats to Sustainable Community Governance and Management of Natural Commons." In Community Management and Common Property of Coastal Fisheries in Asia and the Pacific: Concepts, Methods and Experiences, ed. Pomeroy, R. S., ICLARM Conference Proceedings 45. Manila. (1994): 34-50.

Ostrom, Elinor Understanding Institutional Diversity. Princeton University Press (Princeton paperbacks), Princeton, New Jersey. (2005).

Ostrom, Elinor "A Diagnostic Approach for Going Beyond Panaceas." Proceedings of the National Academy of Sciences of the United States of America 104, no. 39, (2007): 15181-15187.

Pistor, Katharina "The Standardization of Law and its Effect on Developing Economies." The American Journal of Comparative Law 50, no. 1, (2002): 97-130. 
Platteau, Jean-Philippe and Anita Abraham "Participatory development in the presence of endogenous community imperfections." Journal of Development Studies 39, no. 2, (2002): 104-136.

Platteau, Jean-Philippe and Frederic Gaspart "The Risk of Resource Misappropriation in Community-driven Development." World Development 31, no. 10, (2003a): 1687-1703.

Platteau, Jean-Philippe and Frederic Gaspart "The 'Elite Capture' Problem in Participatory Development." Working Paper. Centre for Research on the Economics of Development (CRED), Department of Economics, University of Namur, Belgium. (2003b).

Platteau, Jean-Philippe "Monitoring Elite Capture in Community-driven Development." Development and Change 35, (2004): 223-246.

Pomeroy, Robert S. "Community-based and Co-management Institutions for Sustainable Coastal Fisheries Management in Southeast Asia." Ocean and Coastal Management 27, no. 3, (1995): 143-162.

Rao, Vijayendra and Ana M. Ibanez "The Social Impact of Social Funds in Jamaica: A Mixed-Method Analysis of Participation, Targeting and Collective Action in Community Driven Development." Policy Research Working Paper No. 2970. World Bank, Development Research Group, Washington, DC. (2003).

Runge, Carlisle F. "Common Property and Collective Action in Economic Development." World Development 14, no. 5, (1986): 623-635.

Schlager, Edella "Fisher's Institutional Responses to Common-Pool Resource Dilemmas." In Rules, Games and Common-Pool Resources, eds. Ostrom, E., R. Gardner, and J. Walker, University of Michigan Press, Ann Arbor, Michigan. (1994): 247-266.

Schleyer, Christian "Economic and Ecological Transformation Processes in East German Water Management Regimes: The Role of Property Rights and Governance Structure." Environmental Management 34, no. 2, (2003): 281-290.

Theesfeld, Insa "From Power Misuse to Leadership in Bulgaria's Irrigation Sector." Paper presented at the Workshop on the Workshop 4, panel on "New Challenges for the Management of Shared Water Resources". Indiana University, June 3-6, 2009. Bloomington, Indiana, USA. (2009).

Theesfeld, Insa "Irrigation sector in Bulgaria: impact of post-socialist policy reforms." Water Policy 10, no. 4, (2008): 375-389.

Wade, Robert "The Management of Common Property Resources: Finding of Cooperative Solution." World Bank Observer 2, no. 3, (1987): 219-234.

Watzin, Mary C. "Lake Ohrid. Experience and Lessons Learned Brief." Document of the World Bank Lake Ohrid Conservation Project (LOCP). (2006)

World Bank "World Bank Financing to Albania. Pilot Fishery Development Project." Procurement Portfolio. (2000)

Yin, Robert K. Case study research. Design and methods. Sage Publications (Applied social research methods series). Beverly Hills, California. (1994).

Young, Oran R. "Institutional Uncertainties in International Fisheries Management." Fisheries Research 37, no. 1-3, (1998): 211-224. 
